\title{
踵骨関節内骨折の観血的治療経験
}

\author{
医療法人社闷牧会小牧病院

$\begin{array}{rrlll}\text { 田邊 龍 樹・小 牧 } & \text { 亘 } \\ \text { 小 牧 一 麿 } & & \\ \text { 宮崎社会保除病院 } & & & & \\ \text { 本 部 浩 一・黒 } & \text { 沢 } & \text { 治 } \\ \text { 栗 原 典 近・江 夏 } & \text { 剛 } \\ \text { 舩 本 太 郎 } & & \end{array}$

\section{Operative Treatment for Intra-articular Fracture of the Calcaneus}

\author{
Ryuji Tabe, Wataru Komaki, and Ichimaro Komaki \\ Department of Orthopaedic Surgery, Komaki Hospital, Miyazaki, Japan \\ Koichi Honbu, Osamu Kurosawa, Norichika Kurihara, \\ Takeshi Enatsu, and Taro Funamoto \\ Miyazaki Social Insurance Hospital, Miyazaki, Japan
}

\begin{abstract}
Operative therapy was performed on 11 intra-articular fractures of the calcaneus by means of extended lateral approach with calcaneal plate. Preoperatively, all cases were evaluated by Sanders classification. Clinical evaluation was performed by Maxfield score, and nine out of all 11 cases achieved excellent or good results.

Pre-and postoperative changes in radiographic findings were studied. Improvement of the Böhler angle was not necessarily reflected in the clinical results, but on the other hand, improvement of the width index and intra-articular displacement was reflected. This method is considered to be an effective treatment for intra-articular calcaneal fractures.
\end{abstract}

Key words : intra-articular calcaneal fracture（踵骨関節内骨折）， lateral approach (外側アプローチ), open reduction（観血的整復）

は じめに

踵骨関節内骨折に対する観血的治療に関してはさま ざまな報告が散見されるものの未だ意見の一致をみて いない，今回我々は同骨折に対し外側侵入法によるプ レート固定を経験したので若干の文献的考察を加えて 報告する。

\section{対象および方法}

対象は 2001 年 1 月より現在まで本術式を施行した
9 症例 11 足で, 両側例が 2 例に存在した。男性 6 症 例 7 足, 女性 3 症例 4 足であり, 受傷機転は全例高所 よりの転落であった。

手術時年齢は平均 48 歳（26 歳～ 72 歳）, 直接検診 または電話アンケートによる追跡期間は平均 26 ヶ月 （3 ヶ月～42 ヶ月）であった。受傷から手術までの期 間は 5 日から 23 日で, 平均 12 日の待機日数を要した。 原則として初診時即日入院させ，ギプスシーネ固定し， 患肢挙上のうえ患部クーリングとした。

術式は原則として Eastwood の extended lateral 


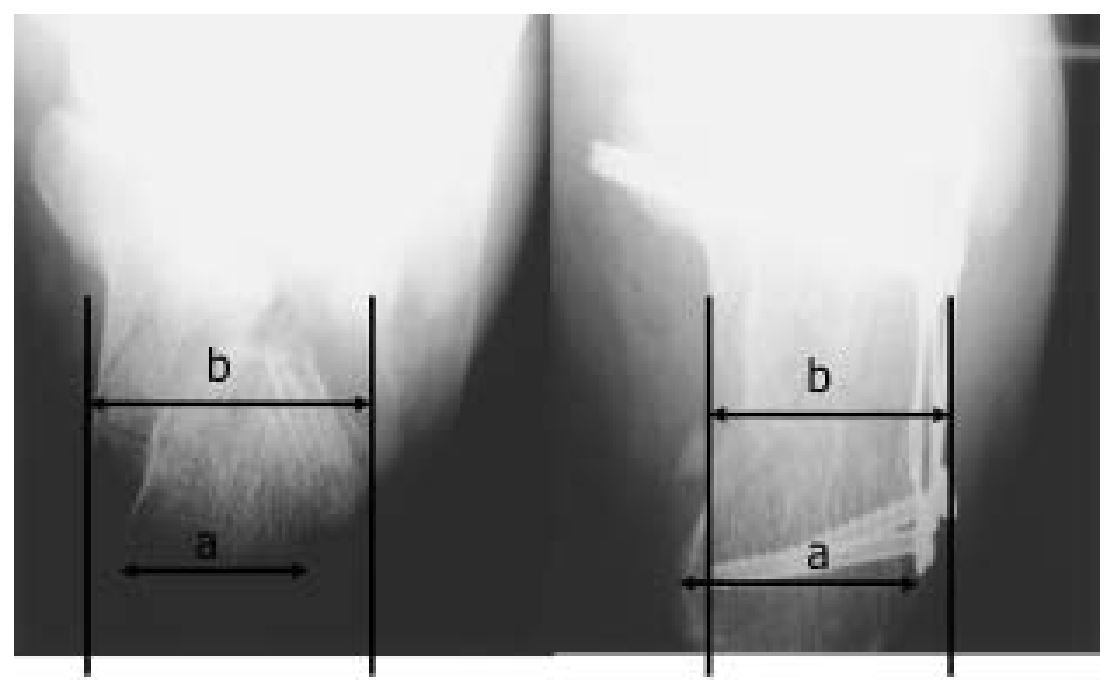

図 1 踵骨横径指数 (Width Index)

Width Index $=100 \times(b-a) / a$

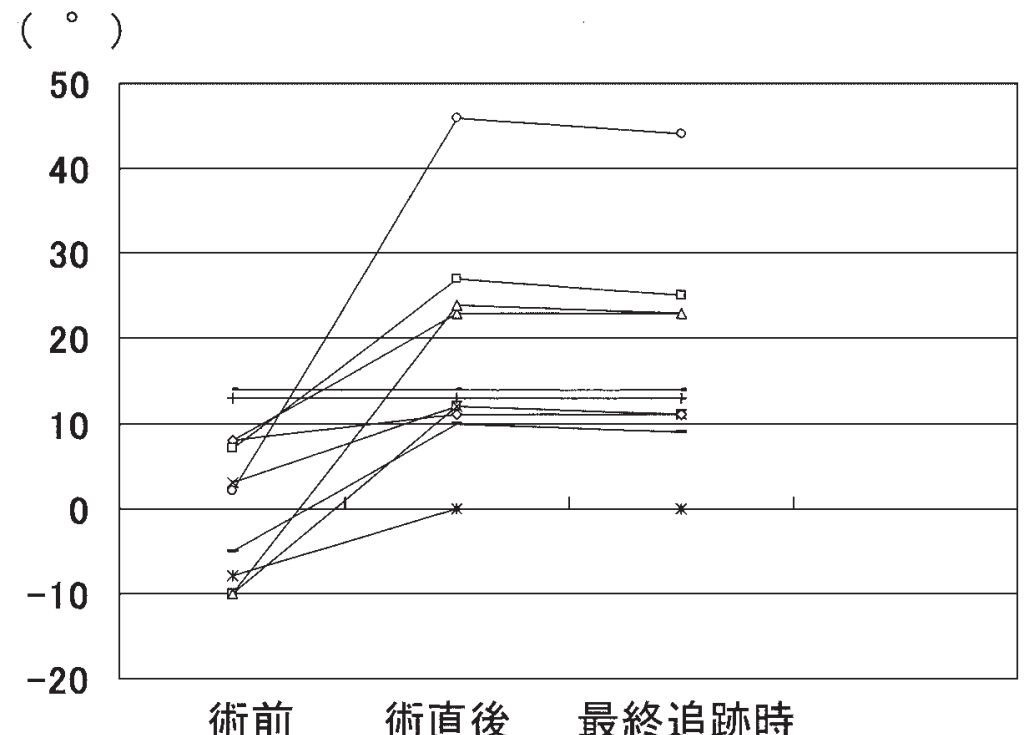

図 2 Böhler 角の推移

approach を用いた. 内固定材は ACE calcaneal plate を9 足に, AO calcaneal plateを 2 足に使用した。骨 移植は全例施行しなかった。

術前に全例で CT を施行し術前骨折型を Sanders 分類にておこなった. 術前後の X 線学的検討は Böhler
角を単純 X 線側面像にて，踵骨横径増大度を単純 X 線軸位像にて ${ }^{4)}$ (図 1), さらに後距踵関節面の適合 性を術後Anthonsen 撮影または CTにて計測した。 臨床評価は Maxfield の評価基準を用いた ${ }^{1)}$ 。すな わち Excellent：愁訴なく ADL 上支障がない, Good 


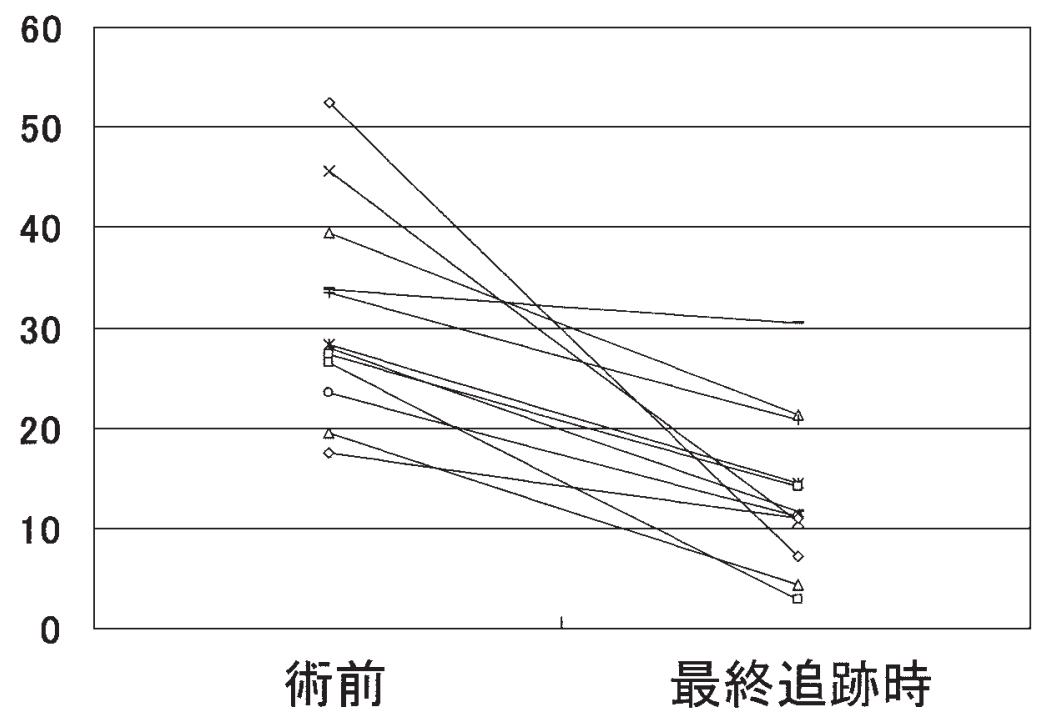

図 3 踵骨横径指数の变化

表 1 後距踵関節面のずれと臨床成績

\begin{tabular}{c|cccc}
\hline \hline & Excellent & Good & Fair & Poor \\
\hline $1 \mathrm{~mm}$ 未満 & 2 & 2 & & \\
$1 \mathrm{~mm} \sim 2 \mathrm{~mm}$ 未満 & 1 & 3 & & \\
$2 \mathrm{~mm} \sim 3 \mathrm{~mm}$ 未満 & & 1 & 1 & \\
$3 \mathrm{~mm}$ 上 & & & 1 & \\
\hline
\end{tabular}

: 何らかの愁訴はあるが ADL 上支障がない, Fair : 疼痛・腫脹有し, ADL 上支障がありそして Poor : 職 業変更を有するほどの後遺症ありの 4 段階で行った.

\section{結果}

術前骨折型はSanders 分類 type II が 2 足, type III 7 足, type IVが 2 足と粉砕度の重症例が多かっ た.

Böhler 角の術前後の推移に掞いては 2 足に若干の 矯正損失を認めたものの術直後の角度増大は最終追跡 時までほぼ保たれていた（図２）．３足に術前後でほ とんど増大のない症例が存在したものの, 同症例の臨 床評価においては Excellent が 1 足, Good が 2 足で あり, Böhler 角の増大が必ずしあ臨床評価に反映さ れていなかった。

踵骨横径指数は全例において術後減少しており良好 な矯正が得られていた (図 3 )。横径指数の改善度が
低かった 2 例に術後腓骨筋腱炎が出現した。

後踵骨関節面の適合性においては，段差が $1 \mathrm{~mm}$ 未満の関節面の適合性が得られた症例は 11 足中 4 足, 関節面の不適合は 7 例であった。関節面の不適合が大 きくなると臨床成績は低下する傾向にあった（表 1 ）. 術前後の合併症においては, 術前水泡出現例が 2 足 で認められ，水泡消退を待って手術施行した，術後皮 膚切開断端部の皮膚障害を 2 例に認め, 1 例は保存的 に改善したが，1例は再縫合を余儀なくされた。また 術後腓骨筋腱炎を 2 例に，軽度の感覚障害を 3 例に認 めたが経過とともに保存的に改善した。

\section{症例}

【症例 1 】 26 歳男性土木作業員, 作業中 $2 \mathrm{~m}$ の高さ より転落受傷. Depression 型 Sanders 分類 type II A であった。受傷後 7 日目で手術施行, Böhler 角は 術前 $8^{\circ}$ から術後 $23^{\circ}$, 横径指数は術前 45.5 から 10.7 , 術後の関節面の段差 $1 \mathrm{~mm}$, 臨床成績は Good であっ た (図 4 ).

【症例 2】47 歳男性大工, $5 \mathrm{~m}$ の高さより仕事中転 落, Gastilo type II の開放創を踵骨内側に伴ってい た. Depression 型 Sanders 分類 type III AB であっ た. 受傷後 9 日後に手術施行, Böhler 角は術前 $8^{\circ}$ か ら術後 $11^{\circ}$, 横径指数は術前 52.4 から 7.1 , 術後の関 


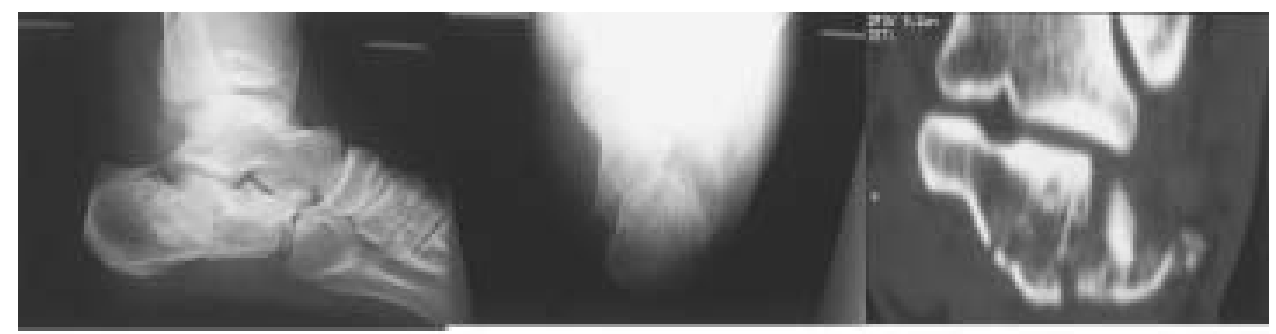

術前

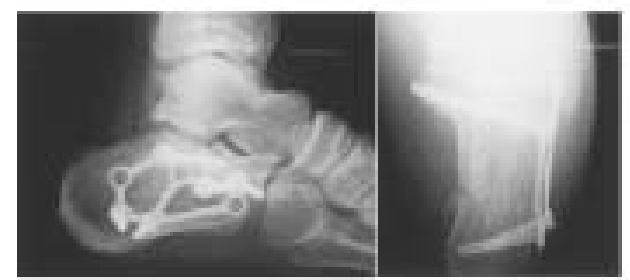

術後 6 ヶ月

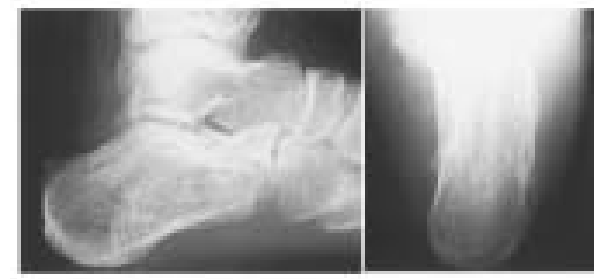

術後 18 ヶ月

図 4 症例 1, 26 歳, 男性, Sanders 分類 type II A
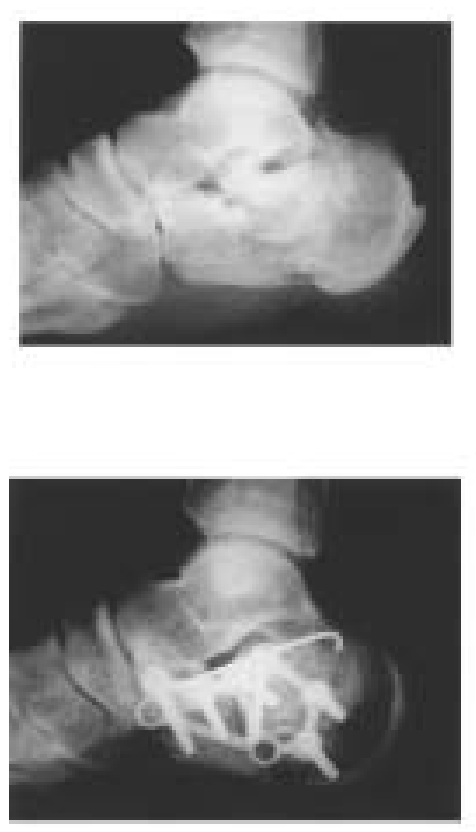

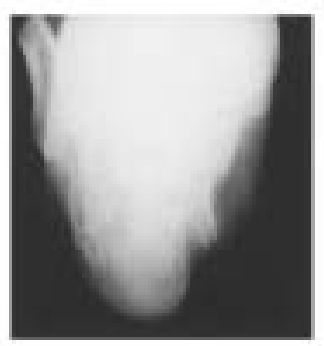

術前
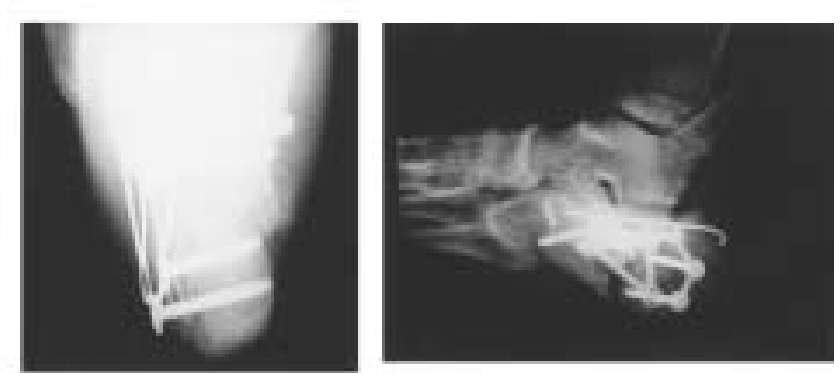

術後 3 ヶ月
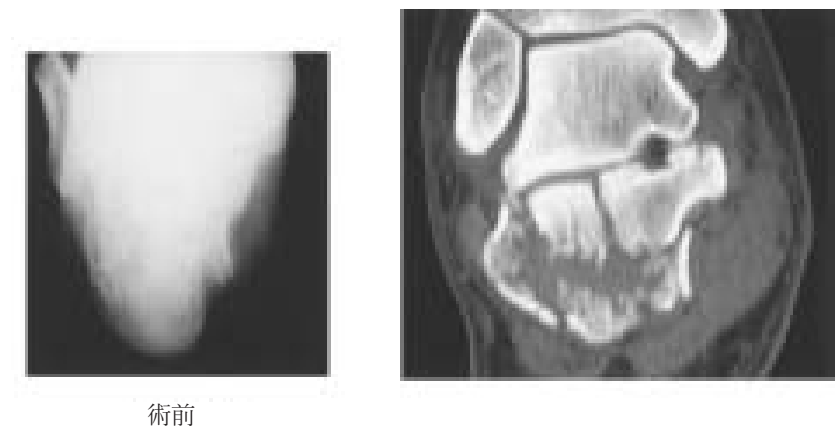

図 5 症例 2, 47 歳, 男性, Sanders 分類 type III AB 
節面の段差 $1.5 \mathrm{~mm}$, 術後 3 ヶ月の現在仮骨形成不十 分なるも現職に復帰臨床成績 Good であった（図 5 ).

\section{考察}

以前我々は踵骨骨折に対しては骨折型のいかんにか かわらずWesthues 法を選択していたが，特にDepression 型の関節内骨折に拈いては疼痛遺残例を経 験していたため 2001 年以降は Depression 型の関節 内骨折に対しては外側進入によるプレート固定を選択 するようにしている。

踵骨骨折の治療成績に関係する因子において，さま ざまな報告がなされている. Sanders らは CT により 4 群に分類し関節面の粉砕が高度になるほど臨床評価 も低下したとした 2)3). 自験例では 11 足中 9 足が type III，IVであったが Excellent とGood の症例が 11 足中 9 足 (82.9\%) であり Sanders らの成績とほぼ 同等であった。臨床成績とX 線成績関係の有無につ いて，様々な報告が散見され，一致した見解は得られ ていない．自験例では Böhler 角の増大が必ずしも臨 床評価に反映されていなかった。一方踵骨の解剖学的 整復の指標である横径指数ならびに関節面の段差にお いては臨床評価に反映される傾向にあった。術後成績 関連因子と後遺障害の関係において外側壁の突出は腓 骨筋腱炎を，関節面の骨折部位および不整は関節症性
変化を招聘するといわれており，すなわち横径指数の 改善と関節面の解剖学的整復が臨床成績の向上につな がると考えられる。

本法は外側進入法の最大の問題点であるとされる皮 膚障害に留意すれば，非常に合理的な方法であると思 われる。

\section{結語}

(1) 外側侵入によるプレート固定した踵骨関節内骨折 の 11 足について報告した。

(2) 本症例に関して，踵骨横径指数の改善と関節面の 良好な整復が臨床評価に反映される傾向にあった。

\section{参 考 文 献}

1) Maxfield, J. E., et al. : Open reduction of fractures of the calcaneus. J. Bone Joint Surg., 37-A : 99-106, 1955.

2) Sanders, R., et al. : Operative treatment in 120 displaced intraarticular calcaneal fractures. Clin. Orthop., $290: 87-95,1993$.

3) Sanders, R. : Displaced intra-articular fractures of the calcaneus. J. Bone Joint Surg., 82-A : 225-246, 2000.

4）杉本和也：踵骨関節内骨折に対する新しい治療法につ いて. 奈医雑：267-292，1989. 